\title{
Rhinebothrium jaimei sp. n. (Eucestoda: Rhinebothriidea: Rhinebothriidae): a new species from Neotropical freshwater stingrays (Potamotrygonidae)
}

\author{
Fernando P. L. Marques ${ }^{1}$ and Florian B. Reyda ${ }^{2}$
}

\author{
${ }^{1}$ Departamento de Zoologia - Instituto de Biociências, Universidade de São Paulo, Cidade Universitária, São Paulo, SP, Brazil; \\ ${ }^{2}$ Biology Department \& Biological Field Station, State University of New York, College at Oneonta, NY, USA
}

\begin{abstract}
Neotropical freshwater stingrays (Batoidea: Potamotrygonidae) host a diversity of parasites, including some, like their hosts, that are marine-derived. Among the parasites of potamotrygonids, the cestode fauna is the most diverse, with multiple genera having been reported, including genera endemic to the freshwaters of the Neotropics and genera that have cosmopolitan distributions. Recent efforts have been made to document the diversity of cestodes of this host-parasite system and to refine the taxonomy of parasite lineages. The present study contributes to our knowledge of Rhinebothrium Linton, 1890, a diverse cosmopolitan genus of rhinebothriidean cestode, with 37 species reported from marine batoids, one species from a freshwater stingray in Borneo and six species from potamotrygonids. Rhinebothrium jaimei sp. n. is described from two species of potamotrygonids, Potamotrygon orbignyi (Castelnau) (type host) and Potamotrygon scobina Garman, from Bahía de Marajó of the lower Amazon region. It can be distinguished from most of its marine congeners via multiple attributes, including its possession of two, rather than one, posteriormost loculi on its bothridia and the lomeniform shape of its bothridium that is wider anteriorly. In addition, R. jaimei $\mathrm{sp} . \mathrm{n}$. can be distinguished from the six Rhinebothrium species described previously from potamotrygonids based on a unique combination of morphological features. Despite extensive stingray cestode sampling efforts throughout all major Neotropical river systems, we found that unlike most species of potamotrygonid Rhinebothrium species, which are widespread, R. jaimei sp. n. is restricted to the Bahía de Marajó. The discovery of this new species of Rhinebothrium in Bahía de Marajó, an area in which potamotrygonids occur sympatrically with some species of euryhaline batoids (e.g. Dasyatis spp.) and share some trophic resources, suggest that modern ecological processes may be contributing to the distribution patterns of cestodes infecting potamotrygonids.
\end{abstract}

Keywords: Cestoda, taxonomy, Amazon, biogeography, host specificity, Neotropics, Brazil

The helminthological fauna of the Neotropical freshwater stingrays has attracted the attention of parasitologists and biogeographers alike since the seminal study of Brooks et al. (1981) that used the hypothesised relationships among freshwater and marine lineages of cestodes to infer the biogeographic history of this unique group of elasmobranchs. According to the authors, this endemic group of stingrays - now represented by approximately 30 recognised species of restricted freshwater elasmobranchs and found in most of the major river basins of South America (Fontenelle et al. 2014) - was derived from a tropical eastern Pacific marine ancestor during the Cretaceous. Since its inception, what became a classic example of co-evolutionary study (Blair 1994), has received criticism owing to its lack of analytical protocol and the taxonomic bias upon which the inferences based on parasitological data were drawn (Straney 1982, Caira 1994, Lovejoy 1997). Meanwhile, subsequent morphological and molecular based phylogenies have suggested that the ancestor of potamotrygonids colonised South
America via marine incursion in northern South America during the Paleogene Period, specifically between the early-Miocene and mid-Eocene (22.5-46.0 mya; see Lovejoy et al. 1998, Carvalho et al. 2004).

Despite the controversies surrounding the sister-taxon of Potamotrygonidae and its area of derivation, it is generally accepted that Potamotrygonidae is a monophyletic taxon derived from a marine ancestor. Thus, it is not surprising that the cestode fauna infecting potamotrygonids includes three genera also found in marine elasmobranchs: Acanthobothrium Blanchard, 1848, Anindobothrium Marques, Brooks et Lasso, 2001 and Rhinebothrium Linton, 1890. In addition, four endemic genera of tapeworms have been described from this system: Nandocestus Reyda, 2008, Paroncomegas Campbell, Marques et Ivanov, 1999, Potamotrygonocestus Brooks et Thorson, 1976 and Rhinebothroides Mayes, Brooks et Thorson, 1981.

Rhinebothrium was first described by Linton (1890) to receive $R$. flexile Linton, 1890, a parasite of the roughtail 
stingray, Dasyatis centroura (Mitchill), from the western Atlantic off the coast of Massachusetts, USA. After more than a century of taxonomic history, the genus is represented by 44 valid species (Healy 2006, Reyda 2008, Reyda and Marques 2011, Menoret and Ivanov 2011) that are parasites of most families of batoids (e.g. Arhynchobatidae, Dasyatidae, Myliobatidae, Potamotrygonidae, Rhinobatidae, Rhynchobatidae, Urolophidae, Urotrygonidae and Zanobatidae) from all over the world (see Caira et al. 2012). Despite the fact that the greatest diversity of Rhinebothrium resides in marine waters, $R$. megacanthophallus Healy, 2006 was described from the strictly freshwater ray Himantura polylepis (Bleeker) from the Kinabatangan River, Malaysia (Borneo) and six species are recognised as parasites of potamotrygonids.

Rego and Dias (1976) were the first to report a species of Rhinebothrium from potamotrygonids, $R$. paratrygoni Rego et Dias, 1976 from an unknown species of Potamotrygon Garman from Rio Salobra, La Plata Basin, Brazil. Our knowledge of the diversity Rhinebothrium inhabiting potamotrygonids remained stationary for more than three decades until Reyda (2008) recognised $R$. copianullum Reyda, 2008 in Paratrygon aiereba (Müller et Henle) from Boca Manu, Rio Madre de Dios, Amazon Basin, Peru. It was later found in other locations and host species throughout the Amazon Basin (Reyda and Marques 2011).

Later, Menoret and Ivanov (2009) described R. paranaensis Menoret et Ivanov, 2009 in Potamotrygon motoro (Müller et Henle) from Rio Colastiné, La Plata Basin, Argentina. Shortly after, this species was considered a junior synonym of $R$. paratrygoni by Reyda and Marques (2011) in their most recent review of the Neotropical freshwater lineages of Rhinebothrium. In their review, Reyda and Marques (2011) described two additional species of Rhinebothrium from potamotrygonids: $R$. brooksi Reyda et Marques, 2011 in Paratrygon aiereba and Potamotrygon orbignyi (Castelnau) from the Rio Negro and Rio Xingú, Amazon Basin, Brazil, and R. fulbrighti Reyda et Marques, 2011 in P. orbignyi and in an undescribed species of Potamotrygon from Bahía de Marajó, lower Amazon region, and from the lower Rio Tapajós, Brazil. Finally, Menoret and Ivanov (2011) described $R$. corbatai Menoret et Ivanov, 2011 and R. mistyae Menoret et Ivanov, 2011 in Potamotrygon motoro from Rio Colastiné, La Plata Basin, Argentina.

\section{MATERIALS AND METHODS}

During the period of October to November 2003, a total of 108 stingrays, including eight dasyatids (Dasyatis colarensis Santos, Gomes et Charvet-Almeida, $\mathrm{n}=2$ specimens; D. geijskesi Boeseman, $\mathrm{n}=2 ;$ D. guttata (Bloch et Schneider), $\mathrm{n}=4$ ) and 100 potamotrygonids (Paratrygon aiereba, $\mathrm{n}=1$; Plesiotrygon iwamae Rosa, Castello et Thorson, $\mathrm{n}=7$; Potamotrygon motoro, $\mathrm{n}=32$; Potamotrygon orbignyi, $\mathrm{n}=18$; Potamotrygon scobina Garman, $\mathrm{n}=27$; and Potamotrygon sp., $\mathrm{n}=15$ ) were collected from Bahía de Marajó, municipality of Colares, State of Pará, Brazil (055'35"S; 48¹7'25"W) and Igarapé do Urubu, Rio Arari, municipality of Cachoeira do Arari, State of Pará, Brazil (059'58"S; $\left.48^{\circ} 57^{\prime} 53^{\prime \prime}\right)$ ). Stingrays were collected either using a hand net, known locally as 'rapiché' beach seine, or long line, following the guidelines of a collecting permit issued to F.P.L.M. by the Environmental Ministry of the Brazilian Federal Government (IBAMA Proc. no. 02001.007961/2002-31 issued 8 Jan 2003). Details for the collecting information can be found in http://tapewormdb. uconn.edu/index.php/hosts/specimen_search/elasmobranch.

After collection and euthanasia, the spiral intestine of each stingray was removed, opened with a mid-ventral incision and examined for parasites with a dissecting microscope. Cestodes were placed in formalin diluted from $40 \%$ to $4 \%$ with $0.6 \%$ saline. After several days specimens were transferred to $70 \%$ ethanol for storage. In addition, the spiral intestines of all stingrays collected were also fixed in formalin diluted from $40 \%$ to $4 \%$ with $0.6 \%$ saline and secondarily examined in the laboratory. Cestode specimens prepared as whole mounts for light microscopy were hydrated in a graded ethanol series, stained in Delafield's or Mayer's hematoxylin, dehydrated in a graded ethanol series, cleared in methyl salicylate, and mounted on glass slides in Canada balsam.

Specimens for histological sectioning were embedded in paraplast and sectioned at $8 \mu \mathrm{m}$ intervals using an Olympus CUT4060 retracting rotary microtome. Sections were mounted on glass slides flooded with $2.5 \%$ sodium silicate and dried on a slide warmer for 4 to $8 \mathrm{~h}$. Cross sections of mature proglottids and longitudinal sections of scoleces were prepared. Sections were stained with Delafield's hematoxylin and counterstained with eosin, dehydrated in a graded ethanol series, cleared in xylene, and mounted in Canada balsam. A portion of each worm sectioned was prepared as a whole mount, as above, and kept as a voucher.

Scoleces of two specimens were prepared and examined with scanning electron microscopy (SEM). Each scolex prepared for SEM was cut from its strobila with a scalpel and the strobila was prepared as a whole mount, as described above, and kept as a voucher. SEM specimens were hydrated in a graded ethanol series, transferred to $1.5 \%$ osmium tetroxide overnight, dehydrated in a graded ethanol series and placed in hexamethyldisilisane (HMDS, Ted Pella Inc., Redding, CA, USA) for $15 \mathrm{~min}$. They were allowed to air dry and were subsequently mounted on carbon tape on an aluminum stub. They were sputter-coated with, $250 \AA$ of gold/palladium and examined with a FEI Nova Nano 450 (University of Connecticut) field emission scanning electron microscope.

All cestode specimens prepared as whole mounts, as histological sections, as SEM specimens, and as vouchers, were deposited at Museu de Zoologia da Universidade de São Paulo, São Paulo, SP, Brazil (MZUSP), the United States National Museum, Smithsonian Institution, Washington, D.C., USA (USNM), the Lawrence R. Penner Parasitology Collection, University of Connecticut, Storrs, Connecticut, USA (LRP) and the Institute of Parasitology of the Biology Centre of the Czech Academy of Science, České Budějovice, Czech Republic (IPCAS).

Morphometric data were obtained from whole mounts, including those that served as vouchers for SEM using a Zeiss Axioscope 2 or a Leica DM2500 to obtain photographic documentation, Fiji/ImageJ (Schindelin et al. 2012) to process the images and WormBox (Vellutini and Marques 2014) to compute the data. Only specimens possessing proglottids that were mature (i.e. with distinctly formed male and female genitalia) or further developed (e.g. with sperm-filled vas deferens and atrophied testes) were 


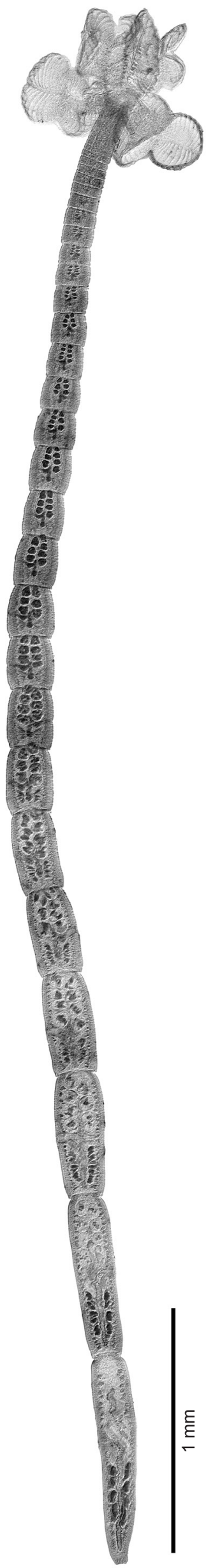

Fig. 1. Light micrograph of the holotype of Rhinebothrium jaimei sp. $\mathrm{n}$. from Potamotrygon orbignyi (Castelnau) (MZUSP 7758). measured in this study. Measurements of all genitalia were taken from terminal proglottids, unless terminal proglottids were further developed, in which cases measurements of testes were only taken from subterminal mature proglottids. Measurements are presented as ranges and number of specimens from which the variable was taken given in parentheses. Repeated measurements for number and dimensions of testes and dimensions of vitelline follicles were averaged per individual. All measurements are in micrometres unless otherwise stated. Line drawings were prepared with the aid of a camera lucida attached to a Zeiss Axioscope 2. Terminology used for microthrix types follows that of Chervy (2009) and terminology for shape of bothridia is from Clopton (2004).

\section{RESULTS}

Rhinebothrium jaimei sp. n.

Figs. 1-4

ZooBank number for species:

urn:Isid:zoobank.org:act:2EC16146-1330-4D4C-AB42-374A60DA6E9A

Description (based on whole mounts of seven complete mature worms, six incomplete mature worms; cross sections of one strobila, longitudinal sections of one scolex, and two scoleces prepared for SEM): Worms (Fig. 1) euapolytic, craspedote, $3.06-6.55 \mathrm{~mm}(\mathrm{n}=7)$ long, greatest width 524-877 $(\mathrm{n}=7)$ at level of scolex; 18-33 $(\mathrm{n}=6)$ proglottids per worm. Scolex (Figs. 2A, 4A) consisting of scolex proper bearing 4 stalked bothridia. Bothridia lomeniform-shaped (sensu Clopton 2004), constricted at centre, with muscular rims (Figs. 2A, 4A), 305-500 ( $\mathrm{n}=3$ ) long; anterior half of bothridium 246-323 $(\mathrm{n}=5)$ wide, slightly wider than posterior half of bothridium 217-268 $(n=5)$ wide, divided by 23-26 $(n=3)$ transverse septa and 1 medial longitudinal septum into 49-55 loculi. Medial longitudinal septum extending from posterior margin of anteriormost loculus to posterior margin of bothridium. Stalks 107-171 $(\mathrm{n}=4)$ long, 64-117 $(\mathrm{n}=4)$ wide, attached to bothridia at middle or slightly posterior to middle of bothridium. Cephalic peduncle lacking; neck varying in length.

Entire proximal surface of bothridia covered with acicular filitriches (Fig. 4C); acicular filitriches at greatest density near edge (Fig. 4B). Proximal bothridial surface except for edge (Fig. 4B), covered with gladiate spinitriches (Fig. 4C). Cilia observed near edge of proximal bothridial surface (Fig. 4B). Distal surfaces of bothridia with coniform spinitriches and acicular filitriches throughout septa and loculi (Fig. 4D,E), orientation of both varies between septa and loculi (Fig. 4E). Stalks, neck and strobila with capilliform filitriches.

Majority of proglottids wider than long; mature proglottids $1-4(\mathrm{n}=13)$ in number. Proglottids with sperm-filled vas deferens and atrophied testes $0-4(n=13)$ in number. No gravid proglottids observed on strobila. Terminal proglottid (Fig. 2B) 427-949 $(\mathrm{n}=12)$ long, 126-248 $(\mathrm{n}=12)$ wide, length to width ratio $1.9-6.2(\mathrm{n}=12)$. Genital pores marginal, irregularly alternating, $52-68 \%(n=12)$ of proglottid length from posterior end; surrounded by glandular 


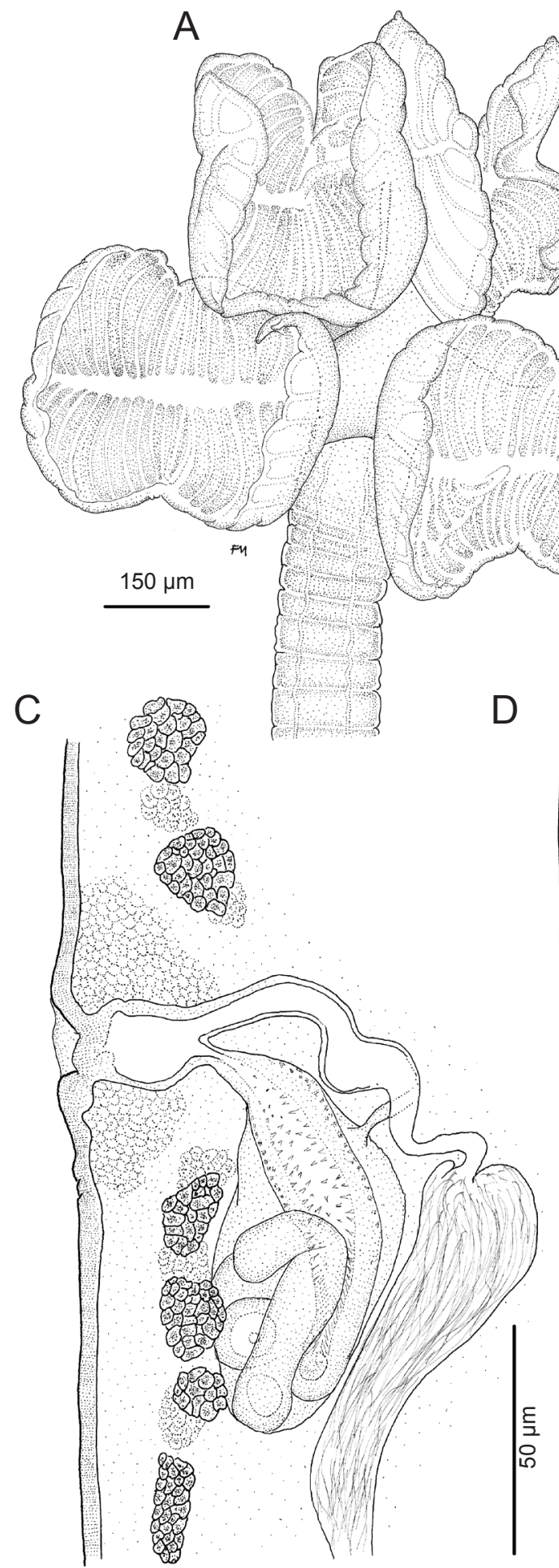

B

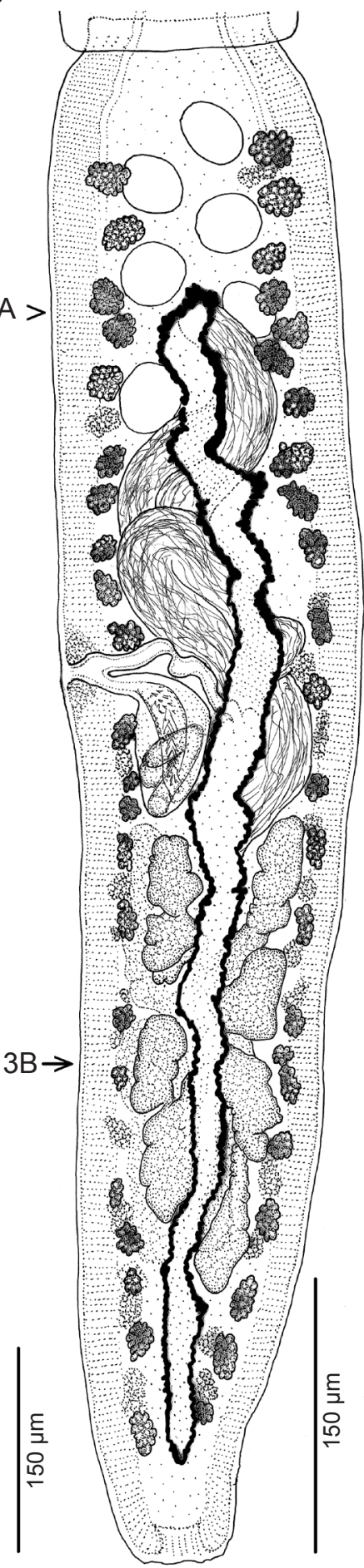

Fig. 2. Line drawings of the holotype of Rhinebothrium jaimei sp. n. from Potamotrygon orbignyi (Castelnau) (MZUSP 7758). A - scolex; B - terminal proglottid in which testes are atrophied; arrows indicate respective positions for sections shown in Fig. 3; C - mature subterminal proglottid; $\mathbf{D}$ - terminal genitalia.

tissue (Fig. 2B,C). Testes in terminal proglottids irregularly oval to circular in dorsal view (Fig. 2B,D), 42-91 $(\mathrm{n}=10)$ long, 27-54 $(\mathrm{n}=10)$ wide, all in primary field, 6-8 $(\mathrm{n}=12)$ in total number, 1 layer deep (Fig. 3A), in 2 irregular columns, extending from near anterior margin of proglottid to level of genital pore, reduced in size as sperm delivered to vas deferens. Vas deferens in terminal proglottids coiled, spanning from anterior margin or near anterior margin of proglottid to level of genital pore. Cirrus sac elongate oval, bent posteriorly, slender in subterminal mature proglottids (Fig. 2D), not extending beyond midline of proglottid, extending posteriorly towards anterior margin of the poral ovarian lobe, containing coiled cirrus. Cirrus sac in terminal proglottids $67-114(\mathrm{n}=10)$ long, 28-72 ( $\mathrm{n}=10)$ wide. Cirrus coiled in cirrus sac, with spinitriches 3.5-4.0 $(\mathrm{n}=4)$ long. 

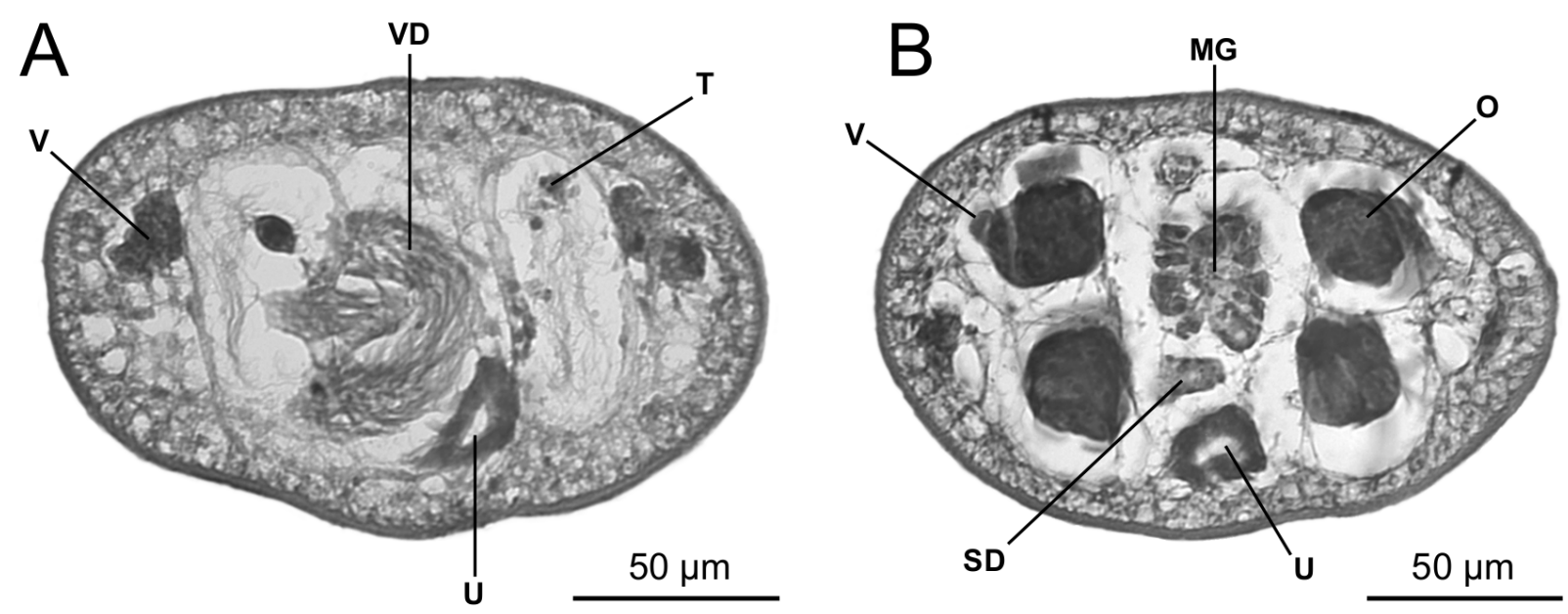

Fig. 3. Photomicrographs of histological sections of Rhinebothrium jaimei sp. n. from Potamotrygon orbignyi (Castelnau) (MZUSP 7760)A - section at level of testes; B - section at level of ovary. Abbreviations: MG - Mehlis' gland; O - ovary; SD - sperm duct; $\mathrm{T}$ - testis; U - uterus; V - vagina; VD - vas deferens.

Vagina thick-walled, sinuous, varying in width along its length (Fig. 2C), extending from ootype along medial line of proglottid to anterior margin of cirrus sac, then laterally to common genital atrium. Vaginal sphincter not observed (Fig. 2C). Anteromedial portion of vagina, adjacent to cirrus sac, greatly expanded (Fig. 2C). Proximal portion of vagina slightly expanded (Fig. 2C). Ovary near posterior end of proglottid, lobulated, inverted A-shaped or $\mathrm{H}$-shaped in terminal proglottid and $\mathrm{H}$-shaped in subterminal proglottids in frontal view, tetra-lobed in cross section (Fig. 3B), symmetrical, 117-368 $(\mathrm{n}=12)$ long, $79-157$ $(\mathrm{n}=12)$ wide at isthmus, occupying $28-47 \%(\mathrm{n}=5)$ of proglottid length; ovarian isthmus located near or slightly anterior to mid-point of ovary. Distance between anterior margin of ovary and genital pore 42-99 $(n=12)$. Mehlis' gland posterior to ovarian isthmus. Vitellarium follicular, vitelline follicles 14-23 $(n=12)$ long, 8-17 $(n=12)$ wide, 1 dorsal and 1 ventral column on each side of proglottid, extending from posterior to anterior margin of proglottid, uninterrupted or slightly interrupted ventrally and/or dorsally by cirrus sac and vagina. Uterus ventral, sacciform, extending from posterior margin of ovary to near anterior margin of proglottid. Free gravid proglottids and eggs not observed.

Type host: Potamotrygon orbignyi (Castelnau).

Additional host: Potamotrygon scobina Garman.

Type locality: Bahía de Marajó, Colares, Pará, Brazil $\left(0^{\circ} 55^{\prime} 35^{\prime \prime} \mathrm{S} ; 48^{\circ} 17^{\prime} 25^{\prime \prime} \mathrm{W}\right)$.

Additional locality: None.

Site of infection: Spiral intestine.

Prevalence of infection: Five of 18 P. orbignyi examined; one of 27 P. scobina examined.

Type material: Holotype (MZUSP 7758); 5 paratypes (MZUSP 7759-7763); 5 paratypes (LRP 8729-8733); 2 paratypes (IPCAS C-699); 2 paratypes (USNM 12832961283297).

Ety mology: The species is named in honour of Jaime Carvalho Jr. who helped us for so many years conduct research in the Amazon.
Remarks. Rhinebothrium jaimei sp. n. can be distinguished from all 44 previously described species of Rhinebothrium with a unique combination of features, including its possession of two posterior loculi, a lomeniform-shaped bothridium that is wider anteriorly, and several quantitative features. It can be distinguished from all but 13 species of Rhinebothrium in its possession of two, rather than one, posterior loculi. Table 1 provides information for the 13 other species of Rhinebothrium that also possess two posterior loculi. The list includes all six Rhinebothrium species previously known to inhabit potamotrygonids. Rhinebothrium jaimei can be easily distinguished from these six species in its possession of a bothridium that is wider anteriorly and lomeniform in shape, and in its possession of fewer proglottids (18-33 vs 53-139 in R. brooksi, 128-880 in $R$. copianullum, 96-100 in R. corbatai, 40-168 in $R$. fulbrighti, 353-974 in $R$. mistyae and 266-1060 in $R$. paratrygoni; see Table 1), despite the observation that $R$. jaime can achieve similar size $(3.1-6.6 \mathrm{~mm})$ to $R$. brooksi (6-27 mm), R. fulbrighti (3.1-18.0 mm), and R. corbatai $(3.3-7.5 \mathrm{~mm})$.

Among Neotropical freshwater species of Rhinebothrium, $R$. jaimei can be further differentiated from $R$. copianullum, $R$. corbatai, $R$. mistyae and $R$. paratrygoni by possessing a smaller number of bothridial loculi (49-55 vs 63-87, 71-75, 75-79 and 63-71, respectively). Although specimens of $R$. jaimei overlap in their number of bothridial loculi with $R$. brooksi and $R$. fulbrighti (49-55 vs 55-65 and 43-53, respectively), it can be further distinguished from the latter two species using other features. Rhinebothrium jaimei has more testes than $R$. fulbrighti (6-8 vs 2-3; see Table 1), and it has smaller cirrus spinitriches than those of $R$. brooksi (3.5-4.0 $\mu \mathrm{m} v s$ 7.6-8.0 $\mu \mathrm{m})$.

Only seven species of Rhinebothrium other than those in Neotropical freshwater stingrays possess two posterior loculi (see Table 1): R. kinabatanganensis Healy, 2006, $R$. ghardaguensis Ramadan, 1984, R. margaritense Mayes et Brooks, 1981, R. rhinobati Dailey et Carvajal, 1976, R. setiensis Euzet, 1955, R. tetralobatum Brooks, 1977 

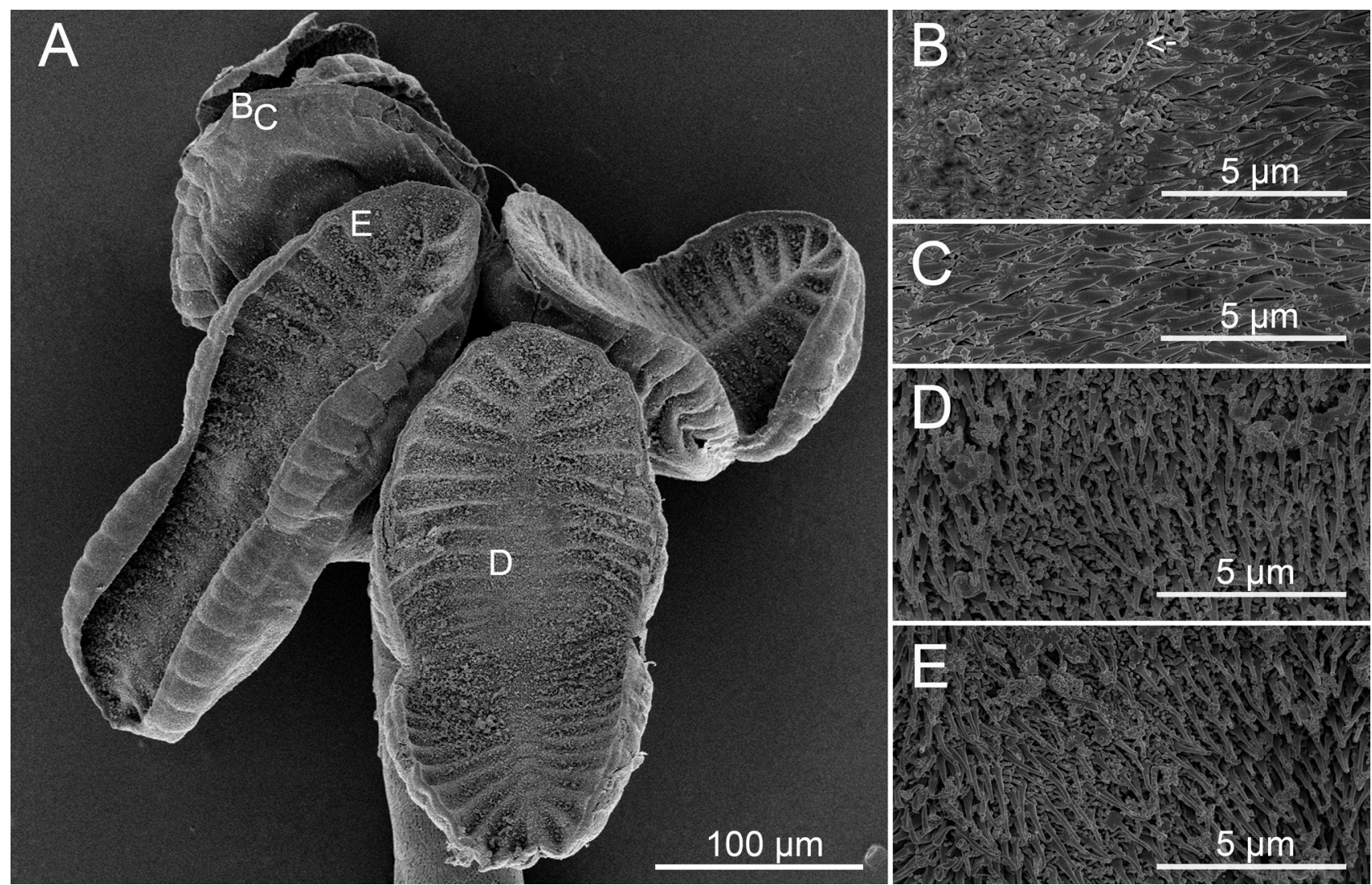

Fig. 4. Scanning electron micrographs of Rhinebothrium jaimei sp. n. from Potamotrygon orbignyi (Castelnau). A - scolex; letters indicate locations of other SEMs; B - proximal bothridial surface near rim; white arrow indicates a cilium; $\mathbf{C}$ - proximal bothridial surface; D - distal bothridial surface near centre of bothridium; $\mathbf{E}$ - distal bothridial surface near a transverse septum.

Table 1. Comparison of species of Rhinebothrium Linton, 1890 that possess two posterior bothridial loculi.

\begin{tabular}{|c|c|c|c|c|c|c|}
\hline Species & $\begin{array}{l}\text { Total length } \\
\quad(\mathrm{mm})\end{array}$ & $\begin{array}{l}\text { No. of } \\
\text { proglottids }\end{array}$ & $\begin{array}{l}\text { No. of } \\
\text { bothridial } \\
\text { loculi }\end{array}$ & $\begin{array}{l}\text { No. of } \\
\text { testes }\end{array}$ & Ecoregion† & Type host \\
\hline \multicolumn{7}{|l|}{ Freshwater species } \\
\hline R. brooksi Reyda et Marques, 2011 & $6-27$ & $53-139$ & $55-65$ & $7-13$ & Neotropial freshwater/Amazon & $\begin{array}{l}\text { Paratrygon aiereba } \\
\text { (Müller et Henle) }\end{array}$ \\
\hline R. copianullum Reyda, 2008 & $10-68$ & $128-880$ & $63-87$ & $4-12$ & Neotropial freshwater/Amazon & Paratrygon aiereba \\
\hline R. corbatai Menoret et Ivanov, 2011 & $3.3-7.5$ & $96-100$ & $71-75$ & $3-5$ & $\begin{array}{l}\text { Neotropial freshwater/La Plata } \\
\text { basin }\end{array}$ & $\begin{array}{l}\text { Potamotrygon motoro } \\
\text { (Müller et Henle) }\end{array}$ \\
\hline R. fulbrighti Reyda et Marques, 2011 & $3.1-18.0$ & $40-168$ & $43-53$ & $2-3$ & Neotropial freshwater/Amazon & $\begin{array}{l}\text { Potamotrygon orbignyi } \\
\text { (Castelnau) }\end{array}$ \\
\hline R. jaimei sp. n. & $3.1-6.6$ & $18-33$ & $49-55$ & $6-8$ & Neotropial freshwater/Amazon & Potamotrygon orbignyi \\
\hline R. kinabatanganensis Healy, 2006 & $2.8-6.4$ & $29-51$ & $33-43$ & $10-15$ & $\begin{array}{l}\text { Central Indo-Pacific/Malaysia } \\
\text { (Borneo) - freshwater }\end{array}$ & $\begin{array}{l}\text { Himantura polylepis } \\
\text { (Bleeker) }\end{array}$ \\
\hline R. mistyae Menoret et Ivanov, 2011 & $20.0-59.9$ & $353-974$ & $75-79$ & $4-7$ & $\begin{array}{l}\text { Neotropial freshwater/La Plata } \\
\text { basin }\end{array}$ & Potamotrygon motoro \\
\hline R. paratrygoni Rego et Dias, 1976 & $8-80$ & $266-1060$ & $63-71$ & $4-9$ & $\begin{array}{l}\text { Neotropial freshwater/La Plata } \\
\text { basin }\end{array}$ & Potamotrygon sp. \\
\hline \multicolumn{7}{|l|}{ Marine species } \\
\hline R. ghardaguensis Ramadan, 1984 & $20-25$ & $22-25$ & $34-36$ & 15 & Western Indo-Pacific: Red Sea & $\begin{array}{l}\text { Taeniura lymma } \\
\text { (Forsskål) }\end{array}$ \\
\hline R. margaritense Mayes et Brooks, 1981 & 5.7 & $75-100$ & $26-28$ & $3-6$ & $\begin{array}{l}\text { Tropical Northwest Atlantic/ } \\
\text { Caribbean }\end{array}$ & $\begin{array}{l}\text { Dasyatis guttata } \\
\text { (Bloch et Schneider) }\end{array}$ \\
\hline R. rhinobati Dailey et Carvajal, 1976 & $1.8-2.8$ & $18-33$ & 23 & 2 & $\begin{array}{l}\text { Warm Temperate Southeastern } \\
\text { Pacific }\end{array}$ & $\begin{array}{l}\text { Rhinobatos planiceps } \\
\text { Garman }\end{array}$ \\
\hline R. setiensis Euzet, 1955 & $15-18$ & $25-30$ & 47 & $27-34$ & $\begin{array}{l}\text { Temperate Northern Atlantic/ } \\
\text { Mediterranean Sea }\end{array}$ & $\begin{array}{l}\text { Myliobatis aquila } \\
\text { (Linnaeus) }\end{array}$ \\
\hline R. tetralobatum Brooks, 1977* & $15-30$ & $82-100$ & $50-54$ & 2 & $\begin{array}{l}\text { Tropical Northwest Atlantic/ } \\
\text { Caribbean }\end{array}$ & $\begin{array}{l}\text { Himantura schmardae } \\
\text { (Werner) }\end{array}$ \\
\hline R. tumidulum (Rudolphi, 1819) & $10-15$ & $80-100$ & 22 & $10-12$ & $\begin{array}{l}\text { Temperate Northern Atlantic/ } \\
\text { Lusitanian or Mediterranean Sea }\end{array}$ & $\begin{array}{l}\text { Dasyatis pastinaca } \\
\text { (Linnaeus) }\end{array}$ \\
\hline
\end{tabular}

No. - number; $\dagger$ modified from Spalding et al. (2007); * observation that $R$. tetralobatum Brooks, 1977 possesses two posterior loculi taken from the examination of paratypes (HWML 20266). 
and R. tumidulum (Rudolphi, 1819). Compared to those, $R$. jaime $i$ has a differently-shaped bothridium and possesses fewer testes than $R$. kinabatanganensis, $R$. tumidulum, $R$. setiensis and $R$. ghardaguensis (6-8 vs 10-15, 10-12, 27-34 and 15, respectively), and it can be distinguished from $R$. margaritense and $R$. tetralobatum by the presence of fewer proglottids (18-33 vs 75-100 and 82-100, respectively). The new species differs from $R$. rhinobati in its larger size (3.1-6.6 $\mathrm{mm}$ vs 1.8-2.8 $\mathrm{mm}$ ), larger number of bothridial loculi (49-55 vs 23) and larger number of testes (6-8 vs 2).

\section{DISCUSSION}

Despite earlier attempts to understand the evolution of the cestode parasites of potamotrygonids (Brooks et al. 1981, Brooks 1992, 1995, Brooks and Amato 1992, Zamparo et al. 1999, Marques 2000), there is still much to be learned about the lineages that comprise this interesting system. While the mechanisms that shaped the composition of the cestode fauna in Neotropical freshwater stingrays remain unknown, we are in the process of recognising the host and parasite lineages that comprise this system, in order to provide the taxonomic refinement to address more complex evolutionary questions. Be that as it may, the underlying assumption of all those attempts was to view each component of helminthological fauna inhabiting potamotrygonids as a result of long historical associations between potamotrygonids and their parasites (see Lovejoy 1997). No room was left to contemplate possible modern ecological processes that might also account for the distribution of cestode species in these hosts. The unique ecological attributes of the type locality and the apparent low prevalence of $R$. jaimei, coupled with its restricted biogeographical distribution, suggest that modern ecological processes may be contributing to the distribution patterns of cestodes infecting potamotrygonids.

The type locality of $R$. jaime $i$ is unique in comparison to most type localities from which the remaining Neotropical freshwater species of Rhinebothrium have been reported. Except for $R$. fulbrighti and $R$. jaimei, both sharing the same type locality, all other species have been described from rivers that are not influenced by the marine environment. The waters of Bahía de Marajó undergo salinity changes throughout tidal cycles and are affected by seasonal changes in the balance of freshwater discharges from the Tocantins River, and to a certain extent the Amazon River, as well as the displacement of the Atlantic Ocean (Almeida et al. 2009). Potamotrygonids have been reported in brackish waters of the Amazon River mouth region and Potamotrygon orbignyi, the typehost of $R$. jaimei, seems to be one of the most tolerant potamotrygonids to brackish water, having been collected in salinities up to 12.4 psu (Almeida et al. 2009). As a result of the salinity dynamics in the region, potamotrygonids and marine stingrays - many of which are known to be euryhaline (see Martin 2005 and references therein) - are found to be syntopic at the type locality of $R$. jaimei.

Rhinebothrium jaimei seems to have relatively lower prevalence among potamotrygonids when compared to $R$. fulbrighti, a sympatric congener. We have sampled $\sim 100$ potamotrygonids from the Bahía de Marajó, 18 of which were identified as Potamotrygon orbignyi, the type host of both species. Reyda and Marques (2011) described $R$. fulbrighti based on over 60 specimens after examining more than 200 specimens assigned to this taxon. Yet, we recovered less than 20 specimens for $R$. jaimei from the same sample of hosts.

The pattern of distribution of $R$. jaimei is also intriguing. Compared to its six congeners from potamotrygonids, $R$. jaimei has a greatly restricted distribution, having only been found in the Bahía de Marajó, despite extensive stingray cestode sampling throughout the Amazon river system (see Reyda and Marques 2011) and the La Plata, Orinoco, and Maracaibo basins (F.P.L.M. - unpubl. data). In contrast, $R$. fulbrighti, which also shares the same type-host and co-occurred with $R$. jaimei in four individuals of $P$. orbignyi from Bahía de Marajó, has been reported as far as up the Amazon river as the mouth of the Tapajós River (Reyda and Marques 2011). Potamotrygon orbignyi is widespread throughout the Amazon and Orinoco basins; hence, host distribution does not explain the restricted distribution of R. jaimei.

The patterns described above could be an intrinsic biological property of this new species, but it is also possible that potamotrygonids are not the primary host of $R$. jaimei. The opportunistic infection of potamotrygonids by marine cestodes should be considered, despite the circumstantial evidence presented. In Bahía de Marajó and Delta of Orinoco, an ongoing study on the trypanorhynch fauna of potamotrygonids revealed the presence of marine species of trypanorhynchs (i.e. species of Prochristianella Dollfus, 1946) in freshwater stingrays. The genus is restricted to the marine environment and has not been found in the samples we have for other potamotrygonids collected in strictly freshwater habitats (B. Schaeffner, Departamento de Zoologia - IB, Universidade de São Paulo, São Paulo, Brazil - unpubl. data).

Pterobothrium crassicolle Diesing, 1850, another trypanorhynch species described on the basis of plerocerci from a variety of teleost fishes from freshwater and estuarine to marine lineages, e.g. Arius felis (Linnaeus), Bagre marinus (Mitchill) - ariid catfishes; Brachyplatystoma flavicans (Humboldt) and B. vaillanti (Valenciennes) - pimelodid catfishes; Epinephelus morio (Valenciennes) - a serranid red-grouper; Hoploerythrinus unitaeniatus (Spix et Agassiz) - the type host and a characiform; and Micropogonias furnieri (Desmarest) - a sciaenid, has also been found in potamotrygonids collected in areas under marine influence (B. Schaeffner - unpubl. data). We also found one specimen of Dasyatis guttata to be infected with one unidentified species of Rhinebothroides, a genus only reported from potamotrygonids thus far, from the Delta of Orinoco (F.P.L.M. - unpubl. data). Therefore, the exchange of cestode fauna between freshwater and marine lineages of batoids could be more common than previously reported.

The infection of potamotrygonids by marine cestodes requires not only syntopic distribution but also overlap in diet or lack of intermediate host specificity. Although no 
data exist on intermediate host specificity for Rhinebothrium, potamotrygonids do share dietary items with marine batoids in estuarine waters. Potamotrygon orbignyi feeds exclusively on insects when restricted to freshwater environments, however, crustaceans became the second most important dietary component in estuarine waters (see Lins 2007, Almeida et al. 2010, Moro et al. 2011). Crustaceans are the primary food for Dasyatis colarensis in Bahía de Marajó and for D. guttata in the northeast coast of Brazil (Silva et al. 2001, Lins 2008). Whether crustaceans could serve as intermediate hosts for some rhinebothriids is unknown. However, it is possible that this local component of the $P$. orbignyi diet could promote an infection of parasites that this host species would not have elsewhere in its distribution.

Whether the pattern observed for $R$. jaimei is contingent on a long historical association with potamotrygonids - as seems to be the case for the other lineages reported in these hosts (see Reyda and Marques 2011) - or, on modern ecological processes, remains an open question. If $R$. jaimei was opportunistically acquired by potamotrygonids, we should expect that a close examination of the cestode fauna of marine batoids in neighbouring marine waters should recover this species in marine or euryhaline batoids. Rhinebothrium jaimei was not found in any of the eight specimens representing three species of Dasyatis Rafinesque (D. colarensis, D. geijskesi and D. guttata) in this study. However, we think that the small number of marine hosts sampled does not allow us to infer that $R$. jamei is not present in these species. The phylogenetic position of $R$. jaimei should shed some light into this discussion. Unfortunately, no material was available for molecular systematic studies. We would expect that, if modern ecological processes are responsible for the observed patterns, future phylogenet- ic studies addressing the sister-group relationships among Rhinebothrium spp., by expanding the available datasets (e.g. Healy et al. 2009, Reyda and Marques 2011, Ruhnke et al. 2015) to include a broader taxonomic and biogeographical representation, should reveal that $R$. jaimei has closer affinities with marine species of Rhinebothrium than with those found in potamotrygonids.

Acknowledgements. Patricia Charvet (SENAI - Departamento Regional do Paraná) and Mauricio Almeida (Museu Paraense Emílio Goeldi) provided assistance in collecting stingrays. Mauro Cardoso Júnior and Natalia Luchetti (Universidade de São Paulo) assisted with laboratory examination of stingray intestines. We thank Bjoern Schaeffner for sharing his preliminary data and providing examples of primarily marine trypanorhynchs infecting potamotrygonids. Finally, we also thank the anonymous reviewers for their valuable comments. This work was performed in part at the Biosciences Electron Microscopy Facility of the University of Connecticut (NSF grant No. 1126100). Janine Caira (University of Connecticut) helped with SEM work and provided valuable input to FR during this study. This work was partially supported with funds from National Science Foundation (NSF) grants, including an NSF Doctoral Dissertation Improvement Grant (DEB No. 0418932) to J. Caira and FR, Partnerships for Enhancing Expertise in Taxonomy (PEET) grants (DEB Nos. 9532943, 0118882), an NSF Planetary Biotic Inventories (PBI) collaborative grant (DEB Nos., 0818696 and 0818823) and an NSF Field Stations and Marine Laboratories (FSML) grant (NSF DBI 1034744). This work was also supported by Judith Shaw Parasitology Fund (University of Connecticut), an Ernst Mayr Travel Grant in Animal Systematics (Harvard Museum of Comparative Zoology, United States of America), a Fulbright Award to FR, the State University of New York College at Oneonta, and the Fundação de Amparo á Pesquisa do Estado de São Paulo, São Paulo State Government, Brazil (No. 2003/01816-2, 2005/012993, and 2008/09436-8) to FM.

\section{REFERENCES}

Almeida M.M, Berthem R.B, Viana A.S., Charvet-AlmeiDA P. 2009: Factors affecting the distribution and abundance of freshwater stingrays (Chondrichthyes: Potamotrygonidae) at Marajó Island, mouth of the Amazon River. Panam. J. Aquat. Sci. 4: 1-11

Almeida M.P., Lins P.M.O. Charvet-Almeida P., Barthem R.B. 2010: Diet of the freshwater stingray Potamotrygon motoro (Chondrichthyes: Potamotrygonidae) on Marajó Island (Pará, Brazil). Braz. J. Biol. 70: 155-162.

Blair D. 1994: So many parasites and so little time! Review of Parascript: parasites and the language of evolution. Syst. Biol. 43: 296-298.

Brooks D.R. 1992: Origins, diversification, and historical structure of the helminth fauna inhabiting neotropical freshwater stingrays (Potamotrygonidae). J. Parasitol. 78: 588-595.

Brooks D.R. 1995: Neotropical freshwater stingrays and their parasites: a tale of an ocean and a river long ago. J. Aquaricult. Aquat. Sci. 7: $5-61$.

Brooks D.R., Амато J.F.R. 1992: Cestode parasites in Potamotrygon motoro (Natterer) (Chondrichthyes: Potamotrygonidae) from southwestern Brazil, including Rhinebothroides mclennanae sp. n. (Tetraphyllidea: Phyllobothriidae), and a revised host-parasite checklist for helminths inhabiting neotropical freshwater stingrays. J. Parasitol. 78: 393-398.

Brooks D.R., Thorson T.B., Mayes, M.A. 1981: Fresh-water stingrays (Potamotrygonidae) and their helminth parasites: testing hypotheses of evolution and coevolution. In: V.A. Funk and

D.R. Brooks (Eds.), Advances in Cladistics. The New York Botanical Gardens, New York, pp. 147-243.

CAIRA J.N. 1994: Parascript: paragon or parody? Review of Parascript: parasites and the language of evolution, by D.R. Brooks and D.A. McLennan. BioScience 44: 771-773.

Caira J.N., Jensen K., Barbeau, E. 2012: Global Cestode Database. World Wide Web electronic publication. University of Connecticut, Storrs, CT, USA. http://www.tapewormdb.uconn. edu, 11/2014.

Carvalho M.R., Maisey J.G., Grande, L. 2004: Freshwater stingrays of the Green River formation of Wyoming (early Eocene), with the description of a new genus and species and an analysis of its phylogenetic relationships (Chondrichthyes: Myliobatiformes). Bull. Am. Mus. Nat. Hist. 284: 1-136.

Chervy L. 2009: Unified terminology for cestode microtriches: a proposal from the International Workshops on Cestode Systematics in 2002-2008. Folia Parasitol. 56: 199-230.

CLOPTON R.E. 2004: Standard nomenclature and metrics of plane shapes for use in gregarine taxonomy. Comp. Parasitol. 71: 130140.

Fontenelle J.P., Da Silva J.P.C.B., Carvalho, M.R. 2014: Potamotrygon limai, sp. nov., a new species of freshwater stingray from the upper Madeira River system, Amazon basin (Chondrichthyes: Potamotrygonidae). Zootaxa 3765: 249-268.

Healy C.J. 2006: Three new species of Rhinebothrium (Cestoda: Tetraphyllidea) from the freshwater whipray, Himantura chaophraya, in Malaysian Borneo. J. Parasitol. 92: 364-374. 
Healy C.J., Caira J.N., Jensen K., Webster B.L., Littlewood, D.T.J. 2009: Proposal for a new tapeworm order, Rhinebothriidea. Int. J. Parasitol. 39: 497-511.

Lins P.M.O. 2007: Composição da dieta da raia de água doce Potamotrygon orbignyi (Castelnau, 1855) (Chondrichthyes: Potamotrygonidae) na região da Ilha de Marajó - Pará. Technical Report, Museu Paraense Emílio Goeldi, Belém, Pará, Brazil, 22 pp.

Lins P.M.O. 2008: Composição da dieta da arraia Dasyatis colarensis Santos, Gomes \& Charvet-Almeida, 2004 (Chondrichthyes, Dasyatidae) na região da Ilha de Colares, Pará. Technica Report, Universidade Federal Rural da Amazônia - Instituto Sócio-Ambiental e dos Recursos Hídricos, Belém, Pará, Brazil, $46 \mathrm{pp}$.

Linton E. 1890: 9. - Notes on Entozoa of marine fishes of New England, with descriptions of several new species. Part II. Report of the United States Commissioner of Fisheries (1887), Washington D.C. 15: 718-899.

LoveJoy N.R. 1997: Stingrays, parasites and Neotropical biogeography: a closer look at Brooks et al.'s hypotheses concerning the origins of Neotropical freshwater rays (Potamotrygonidae). Syst. Biol. 46: 219-230.

Lovejoy N.R, Bermingham E., Martin A.P. 1998: Marine incursion into South America. Nature 396: 421-422.

Marques F.P.L. 2000: Evolution of Neotropical Freshwater Stingrays and Their parasites: Taking into Account Space and Time. PhD Dissertation, University of Toronto, Ontario, Canada, 322 pp.

MARTIN R.A. 2005: Conservation of freshwater and euryhaline elasmobranchs: a review. J. Mar. Biol. Assoc. U.K. 85: 1049 1073.

Menoret A., Ivanov V.A. 2009: A new species of tetraphyllidean (Cestoda) from the Largespot River Stingray, Potamotrygon falkneri (Potamotrygonidae: Chondrichthyes), from the Paraná basin. J. Parasitol. 95: 994-999.

Menoret A., Ivanov V.A. 2011: Descriptions of two new freshwater Neotropical species of Rhinebothrium (Cestoda: Rhinebothriidea) from Potomotrygon motoro (Chondrichthyes: Potamotrygonidae). Folia Parasitol. 58: 178 -186.

Moro G, Charvet P., Rosa R.S. 2011: Aspectos da alimentação da raia de água doce Potamotrygon orbignyi (Chondrichthyes:
Potamotrygonidae) da bacia do Rio Parnaíba, Nordeste do Brasil. Rev. Nordest. Biol. 20: 47-57.

Rego A.A., Dias A.P.L. 1976: Estudos de cestóides de peixes do Brasil. 3.a Nota: Cestóides de raias fluviais Paratrygonidae. Rev. Bras. Biol. 36: 941-956.

REYDA F.B. 2008: Intestinal helminths of freshwater stingrays in southeastern Peru, and a new genus and two new species of cestode. J. Parasitol. 94: 684-699.

ReYda F.B., Marques F.P.L. 2011: Diversification and species boundaries of Rhinebothrium (Cestoda; Rhinebothriidea) in South American freshwater stingrays (Batoidea; Potamotrygonidae). PLoS ONE 6: e22604.

Ruhnke T. R., Caira J. N., Cox, A. 2015: The cestode order Rhinebothriidea no longer family-less: a molecular phylogenetic investigation with erection of two new families and description of eight new species of Anthocephalum. Zootaxa 3904: 51-81.

Schindelin J., Arganda-Carreras I., Frise E., Kaynig V., Longair M., Pietzsch T., Preibisch S., Rueden C., SaAlfeld S., Schmid B., Tinevez J.Y., White D.J., Hartenstein V., Eliceiri K., TomancaK P., Cardona A. 2012: Fiji: an open-source platform for biological-image analysis. Nat. Methods 9: 676-682.

Silva G.B, Viana M.S.R., Furtado-Neto, M.A.A. 2001: Morfologia e alimentação da raia Dasyatis guttata (Chondrichthyes: Dasyatidae) in Mucuripe Bay, Ceará State, Brazil. Arq. Ciên. Mar. 34: 67-75.

Spalding M.D., Fox H.E., Allen G.R., Davidson N., Ferdana Z.A., Finlayson M., Halperin B.S., Jorge M.A., Lombana A., Lourie S.A., Martin K.D., McManus E., Molnar J., RecChia C.A., Robertson J. 2007: Marine ecoregions of the world: a bioregionalization of coastal and shelf areas. Bioscience 57: 573-583.

Straney D.O. 1982: Review of: advances in cladistics. Syst. Zool. 31: $337-341$.

Vellutini B.C., Marques F.P.L. 2014: WormBox. https://github. com/nelas/WormBox, 11/2014.

Zamparo D., Brooks D.R., BArriga, R. 1999: Pararhinebothroides hobergi n. gen. n. sp. (Eucestoda: Tetraphyllidea) in Urobatis tumbesensis (Chondrichthyes: Myliobatiformes) from coastal Ecuador. J. Parasitol. 85: 534-539.

Cite this article as: Marques F.P.L., Reyda F.B. 2015: Rhinebothrium jaimei sp. n. (Eucestoda: Rhinebothriidea: Rhinebothriidae): a new species from Neotropical freshwater stingrays (Potamotrygonidae). Folia Parasitol. 62: 057. 